\title{
Perceptions of Immigrants by the Local People and Administrative Perspectives Regarding the Immigrants of Turkish Origin Who Came to Turkey from Bulgaria: A Case Study of Izmir
}

\author{
Zerrin Toprak Karaman \\ Department of Public Administration, University of Dokuz Eylul, İzmir, Turkey \\ Email: zerrin.toprak@deu.edu.tr
}

Received 22 October 2015; accepted 29 November 2015; published 3 December 2015

Copyright (C) 2015 by author and Scientific Research Publishing Inc.

This work is licensed under the Creative Commons Attribution International License (CC BY).

http://creativecommons.org/licenses/by/4.0/

(c) (i) Open Access

\begin{abstract}
This research on the immigrants of Turkish origin focused on the immigrants "of Turkish Origin" who immigrated to Turkey from Bulgaria after 1980. The research was launched in 2010 and completed in 2012 with respect to the immigrants of Turkish origin living in the regions which were densely settled or in which the immigrants concerned were placed mostly at the periphery of İzmir (Görece, Menderes; Sarnıç; Yeşilova; and Atatürk Neighborhood). The subject of this study is about the social acceptances and rejections between the immigrants of Turkish origin and the Turkish citizens. Although the manuscript does not include the asylum seekers and refugees who have come to Turkey from the eastern and south-eastern borders, who do or do not have a kinship relationship with the peoples living in the country, and who are illegal and within the scope of forced migration, the social perceptions of this matter have also been noted when appropriate.
\end{abstract}

\section{Keywords}

Immigrants of Turkish Origin, Bulgaria, Social Acceptance, Neighborhood

\section{Introduction}

This research on the immigrants of Turkish origin focused on the immigrants "of Turkish Origin" who immigrated to Turkey from Bulgaria after 1980. The research was launched in 2010 and completed in 2012 with re- 
spect to the immigrants of Turkish origin living in the regions which were densely settled or in which the immigrants concerned were placed mostly at the periphery of İzmir (Görece, Menderes; Sarnıç; Yeşilova; and Atatürk Neighborhood). The research sample encompasses the groups that have not become Turkish citizens yet or that acquire Turkish citizenship in the process and those have historical and cultural connections with the settlers of the country and therefore can be defined as people "of Turkish origin". The sending countries to Turkey are known as Macedonia, Kosovo, Albania, Bulgaria, Romania, Greece, and Bosnia and Herzegovina. Turks and relative communities still live in these countries today. Furthermore, immigration into Turkey from such countries as Slovenia, Croatia, Serbia, and Montenegro and especially from the Sancak region is also ongoing.

The subject of this study is about the social acceptances and rejections between the immigrants of Turkish origin and the Turkish citizens. Although the manuscript does not include the asylum seekers and refugees who have come to Turkey from the eastern and south-eastern borders, who do or do not have a kinship relationship with the peoples living in the country, and who are illegal and within the scope of forced migration, the social perceptions of this matter have also been noted when appropriate.

Whilst Turkey has generally been in the position of a transit country before the 2000s, it has now become a receiving country at a gradually increasing rate. These population movements cannot be called short-term seasonal touristic arrivals and departures [1]. The foreign tourists who arrived in Turkey through legal ways stayed for more than six months and even for years and led to the administrative requirement for "the concept of settled foreigner"-an administratively new concept. "The administrative regulations which created a legal convenience for foreigners to acquire properties as real persons and legal entities" in and after 2004 were influential on this sociocultural structural change, which gradually initiated cultural differences from the previous settlers in the country. They attracted the gradually increasing foreign population coming to Turkey generally from Europe and from all around the world particularly to the coastal settlements. The arrivals for investment purposes, as much as the immigration of retired foreigners, created some new mobility to acquire properties starting from the coasts, particularly Antalya and İzmir [2].

While the public opinion recently concerned itself with "the issue of whether national sovereignty and national territories are being lost" with its sociocultural dimension and with the concern over possible competition in the business life even though the legal and voluntary immigration of foreigners concerned did not place any direct burden on economy, the number of asylum seekers exceeded thousands upon the arrivals in Turkey from our eastern border neighbors Iraq (2003 and later) and Syria (2011 and later), which were going on in an undulating fashion with the fear of death due to the political breaks that occurred in their countries. This illegal population mobility towards the eastern \& south-eastern borders of Turkey must doubtlessly be distinguished from the illegal migration activities intended to be controlled within the framework of international legal regulations in the 2000s and referred to in order to live under better conditions. In addition, Iran and Pakistan, which have changed their policies into sending about 4 to 5 million Afghan refugees back to their countries forcefully since the 1980s, have also triggered illegal immigration into Turkey [3].

As of 15 June 2015, one can access contents of news entitled "It is stated that 18 thousand Syrians crossed into Turkey for the last one day... Of millions of people who escaped from war, 1,761,486 took shelter in Turkey" [4]. The failure to know the profiles of those who came among these groups and the terrorist actions [5] encountered in the subsequent processes (20 July 2015, Şanliurfa, 32 deaths) turned the already diminished social sympathy for such an immigration phenomenon into "a social reaction" which emerged in the context of the borders that could not be managed well.

Briefly, those who arrive at the Turkish border gates with the fear of death from their countries, where a human massacre is experienced in a civil war environment in our neighbors on our south-eastern border, are accepted within the rules of human asylum and placed in the areas specified by the administration. The expectation of service created by the asylum seekers concerned, who will definitely place an economic burden on the country and who we hope (?) are temporary, is doubtlessly important in terms of sharing the municipal services at the local level and the limits of tolerance for the taxes which have recently occurred at the national level. Some municipalities were suddenly confronted with serious problems regarding basic services such as social and economic aid, shelter, and procurement of water. The sociocultural and social opposition resulting from this migration build-up, which has almost been left to the door of the local people without making it undergo a rehabilitation process, has been taking its place in the local agenda recently.

Turkey is confronted with different types of migration. Doubtlessly, it could not remain outside the global developments. However, it must consider its rationalistic government at both central and local levels. As it is 
known, the numerical increases in space resulting from the types of migration whether from one region to another within the country or from international types of migration may create multidimensional social reactions which vary in time under new multidimensional impacts (economic, sociocultural, administrative, and political) in these newly settled regions and even in this newly settled country. Especially the fundamental basis for the social reactions of the local people is the failure to set timely and appropriate strategies in public administration. The social perceptions which are given a meaning together with the problems may create either positive or negative outcomes in the formation of the public opinion.

When evaluated as a whole, it is seen that Turkey now hosts population movements for touristic or settlement purposes or forced population movements to the country from all around the world. Besides an analysis of the relations between the immigrants of Turkish origin and the local people, it is clear that one must consider the totality of the migrations owing to push factors like the lack of security due to war and terror in the atmosphere of this migration mobility. Having focused particularly on internal migration until the recent years, Turkey has directed its attention to external migration since the 2000s in parallel with the developments in the population movements. Especially regarding external migration and under the umbrella concept of "foreigner", different administrative structures have been formed, with their reviews going on according to the needs. Nevertheless, external migration management is rather economy-centered, and there exists no strategic action plan on the sociocultural integration between the groups of different ethnic origins and cultural dimensions and the local people. For the accurate identification of the emphases in the text, the terminology is provided below.

\section{Concepts of Migration and Related Definitions}

\subsection{Migration}

Migration is the population mobility which is caused by the obligation of individuals and groups to leave their places of residence for various reasons. Whether the emotions experienced are expressed in a novel or poem language in research, those who are heartbroken are predominantly told or available in memories, along with those who got a chance to move away from the areas they defined as a mother country and to immigrate to the places they could call "my new country" [6].

Regardless of the impact of a person's relation ties, the arrivals under the influence of push or pull factors with different combinations of mobility towards the rural areas or the cities within a country and from varying distances from within the country abroad or vice versa by leaving the place where one is present [7], create various types of internal or external migration. Moreover, the economic, social, cultural, political, administrative, and climate-based dimensions as well as such variables as being under a fatal threat or living in a relatively healthier and more balanced settlement, and being able to use the chance and desire to get appropriate multidimensional opportunities within "the right of freedom of travel" differentiate the types of migration. The characteristics of migrations and their impacts at the local level may differ when such features as gender, biological age (e.g. young and old), and the place of a person in the working life are also added to the definition of migration.

These general titles may be subjected to semantic deepening through subtitles as well. For instance, the word "culture" is an important variable with the broadest network of relationships and multidimensional interpretation. Such richness in definitional positions coming from the history of mankind creates different definitions and perceptions according to their coexistence and the number of times of their coexistence, while it complicates remaining in a single definition. However, instead of studying by the help of internationally accepted indicators that might be related to these definitions, the administrative preferences in Turkey develop towards driving the migration movements into a general framework. Even though the subject of the study encompasses the facilitative priorities developed for the immigrants of Turkish origin by the administration, the legal regulations with an overall approach (generalized) generally create a continuous problem area for "foreign groups". Nevertheless, the basic approach is that it is the fundamental duty of the state to provide settlers, whether foreign or not, with "safe settlements", and "the right to life" preserves its place in the first rank in the list of rights on the network of national and global relations.

There are differences between the legal terminology taken as the basis in effect in Turkey and the international terminology. Thus, it is deemed necessary to provide below the basic migration-related definitions contained in various laws.

Law No. 6458 on Foreigners and International Protection, dated 2013 [8]: In Turkey, the definition of migra- 
tion was directly included in the legislation regulations for the first time with Law No. 6458. According to the definition, migration 'represents the regular migration which refers to foreigners' entry into, stay in, and exit from Turkey through legal ways; the irregular migration which refers to foreigners' entry into, stay in, and exit from Turkey through illegal ways as well as their working in Turkey without a permit; and international protection" (Art. 3/1, Law No. 6458). Indeed, the key words of the definition of migration in this regulation (e.g. foreigner; entry into Turkey through legal ways; entry, stay, and exit through illegal ways; and working without a permit) define the population mobility likely to be contained in the definition of external migration. Therefore, it is actually more appropriate to say "external migration" in this regulation instead of "migration". In this law, a foreigner is defined as "a person who does not have any citizenship bond with the State of Republic of Turkey" (Art. 3/ü, Law No. 6458).

The Settlement Law No. 5543, dated 2006: The Settlement Law stipulated the status of immigrants that might be defined as "external migration" and whose direction of arrival was Turkey-in other words, who immigrated so as to settle in Turkey. When defining "an Immigrant and a Free Immigrant", "the Turkish Origin and the Turkish Culture" were specified as the sine qua non, as it will also be seen from their contents below.

Immigrant: An immigrant is a person who is of Turkish origin, who belongs to the Turkish culture, who comes to Turkey either alone or collectively in order to settle, and who is accepted under this Law (Art. 3/d, Law No. 5543).

Free immigrant: A free immigrant is a person who is of Turkish origin, who belongs to the Turkish culture, who comes to Turkey either alone or collectively in order to settle, and who is accepted into the country on the condition of not requesting to be settled by the state (Art. 3/e, Law No. 5543). As it will also be seen from these definitions, the definition of an "immigrant" is not related to everyone who immigrates but merely to "the Turkish origin and the Turkish culture" in Turkey. Being an immigrant indicates a status whereby one can acquire Turkish Citizenship more easily within legal periods than the other ethnic groups.

There exists no legal definition which directly or indirectly contains the definition of "external or internal migration" apart from these 3 basic regulations and including the provisions of the 1982 Turkish Constitution. A general administrative definition of those who are distinguished from the touristic arrivals in Turkey for a period shorter than six months and who come so as to take part in the education and business lives for longer periods of time has been developed in the recent years. When settlement is in excess of a period of six months, foreigners are evaluated within the definition of "settled foreigner".

\subsection{Refugee}

A foreigner who is outside the country of his/her citizenship as he/she is afraid—for just reasons—of being persecuted owing to his/her race, religion, nationality, membership of a specific social group or political thoughts due to the events taking place in European countries and who is unable to make use of the protection by this country or who is unwilling to make use of it due to the fear concerned or a stateless person who is outside his/her previous country of residence and unable to return there as a result of such events or who is unwilling to return due to the fear concerned shall be granted a refugee status after the status determination procedures (Art. 61, Law No. 5543). Those who come from outside the European countries for similar reasons are also granted a "conditional refugee" status (Art. 62, Law No. 5543) until they settle in the third country.

According to the above-mentioned legal regulations, Turkey skips the process of "seeking asylum", which is implemented in international acceptances, and makes the forced migrations coming from its eastern and southeastern borders come closer to the process of naturalization with a "refugee" status. Upon this political preference, the anxious expectation of whether foreigners will rapidly be turned into "citizens" has arisen in the public opinion. The fact that the phenomenon of Irregular Migration might turn into a maneuver to increase the votes of the Justice and Development Party, which experienced a decline in votes (41\%) and failed to come into power alone in the general elections of 2015, preserves its significance as a disputable issue in the political arena. Considering the acceptances towards the immigrants of Turkish origin, this issue is essential in terms of establishing the social enquiries into the refugees with deep cultural differences onto a ground of reconciliation. This is doubtlessly difficult.

"According to the statistics provided by the World Health Organization, it is expressed that some 30 thousand Syrian female refugees have given birth to children in Turkey since 2011. It is of distinct importance that these women conceived as a result of a rape" [9]. This phenomenon is doubtlessly a tragedy of humanity. 
Although crucial, the phenomena of raping the women and human trafficking are not dwelled on, for they are not the subject of this paper. Nevertheless, there is no doubt that the children and the women with a refugee status must be protected within the scope of the human rights. Another aspect of the issue is that it must be known that the quality of life indicators in the country will be negatively affected owing to the impairment of the quality of life standards.

The process of accepting immigrants into the country is developed in connection with the rights which ensure their visibility in the public sphere. The control of settlers by benefiting from the functional design of settlements has also been an essential administrative means so far [10]. In summary, it does not seem possible for a country to remain unaffected by the changes and developments outside the borders in global mobility. In this case, it is important to question the issue of what can be done in order not to be negatively affected by, or in order to benefit from, the new case and to develop new strategic approaches.

According to the 1982 Turkish Constitution, “...The freedom of settlement can be limited by law in order to prevent the committing of crimes, to ensure social and economic development, to realize sound and regular urbanization, and to protect public properties..." under Article 23, which regulates "the Freedom of Settlement and Travel". Although never implemented in the Republican Turkey to date, in practice, the limiting of the freedom of settlement and travel is possible in a highly wide range of discretion of the administration. External migrations are examined below specifically in terms of the Immigrants of Turkish Origin.

\section{The Pull Factors of İmir in External Migrations}

\subsection{The Immigrants of Turkish Origin}

The immigrants of Turkish Origin who had left their countries of origin settled in various regions of Turkey, which they considered "the mother country", within specific legal procedures by period. There was continuous immigration into Turkey from the Balkan countries as of 1940. According to the years, it is supposed that 140,000 immigrants had come to Turkey by 1944, whereas 155,000 immigrants came to Turkey between 1950 and 1951, 130,000 immigrants in 1978, and around 160,000 immigrants in 1989.

The immigrant groups of Turkish origin were placed in the specific regions they were shown within the framework of a letter of invitation in accordance with the bilateral agreements between the countries in the arrivals during and after the 1940-1950 period, while they were able to settle in the regions they chose with their own preference during and after the 1990s. According to the research sample, the immigrated settlement unit with precedence over the preferences is İzmir [11]. Furthermore, those immigrants who settled in such regions as Çatalca, Bursa, and Dikili, where they could carry on their agriculture-based economic activities such as farming and fishing (their fields of occupation before immigration), later performed a second leap to the province of İzmir. In the in-depth interviews, the presence of common settlement areas where common group belonging predominantly intensified and the immigrant profile gradually became evident was especially stated among the strong elements which affected heading for İzmir, along with the cultural structure of the province and its favorable climatic conditions.

The impact of group belonging is related to the high quality of life in İzmir and its established cultural structure with democratic elements as compared with the other regions. It is expressed by the immigrant opinion leaders that according to the figures of 2010, the estimated number of immigrants from the Balkans is 1 million and 818 thousand in total. This figure does not encompass new migrations and is considered for the groups from Rumelia and the Balkans as a whole within an extensive time frame.

Even though İzmir provides the settlers with services within its life line of good quality in terms of services, another element which stood out in the in-depth interviews with the immigrant groups is the phenomenon of "the failure to find sociocultural reciprocity" [12]. Although it is thought that some 4 million people of identical origin entered Turkey in the 1989-1991 period, it was stated that almost half of those who immigrated in the 1992 returned as they were unable to find the environment of sociocultural acceptance they had expected or the quality of economic life they had got used to in their countries of origin. The regression in the economic conditions in Turkey in the 1990s created a feeling of deprivation in the economic expectations of the immigrants; furthermore, the social acceptances forming indications of the perception of "not regarding them as one of them", whereby the immigrants of Turkish origin were evaluated as "Turco" in Bulgaria or Greece and as "Bulgarian" in Turkey, weakened the willingness to come to Turkey, although it is the mother country. 


\subsection{Immigrant Associations and Visibility in the Public Life}

Knowledge of the profile of immigrants of Turkish origin is essential to evaluate their different types of public needs. Additionally, being aware of the problems of immigrants concerning not only settlement but also visibility in the public life is among the matters that the modern democratic countries pay attention to.

When the characteristic of the spaces they settle in is summarized, first of all, it might be stated that the immigrant groups of Turkish origin mostly live in homogenous communities and inoffensively at the periphery of the city. In other words, the immigrants of Turkish origin and the local settlers who are generally of Turkish origin and who came in the previous periods live in the regions in which they initially settled almost like on islets separated from each other. The local people, who are no more called immigrants, are not considerably aware of the multidimensional problems of the new immigrants. Furthermore, the local people initiate the phenomenon of cultural exclusion themselves, and although the immigrants are "of Turkish origin" in terms of origin, they are identified as "foreigners" in the spatial acceptances.

It is possible to see the most important behavior of immigrants, which in a sense also shows their determination to stay in Turkey permanently, in their desire to develop their sociocultural relations with the local people, whom they relate to the origin that they think they belong to, as much as the administrative relations for which they are dependent on the local and central governments. The failure of public administration to play efficient analytical roles at every level in central and local services and its complicating of sociocultural solidarity with the local people are important outputs of this study.

Among the immigrant groups, the desire to form cultural ties with the local people in order to have themselves accepted easily at the local level directed them to develop strategies and to act strategically on this matter. To pave the way for the enhancement of their quality of life by creating solidarity among them in the political aspect as much as seeking sociocultural and economic support in the region where they were present, the immigrants founded "the immigrant associations", which were effective in creating political gains at the local level. The citizen associations related to the Balkan geography are able to draw the attention of the administration by lobbying successfully. In time, the number of these associations increased by leaps and bounds. According to Law No. 5253 on Associations, dated 2004, "Foreign associations can perform activities or cooperate, open an agency or a branch, found an association or a higher organization or join the founded associations or higher organizations in Turkey with the permission of the Ministry of the Interior provided that the opinion of the Ministry of Foreign Affairs is taken" (Art. 5, Law No. 5253). Association activities at the international level can be performed too. This administrative regulation facilitates the increasing of the visibility of foreigners in the public life among the foreigners who have not acquired the citizenship status yet or who do not have such a request and among the composite groups participated by foreigners and citizens.

According to the figures of 2012, the number of associations is 4,936 in İzmir and the number of citizen associations in this figure is 571 . In other words, the rate of citizen associations is $11.57 \%$ among the total associations. Nevertheless, the solidarity associations of external Turks must be distinguished within this figure. The number of associations reached 6,088 in 2015 [13]. This figure includes 84 associations which were founded with the name "Solidarity Associations with External Turks". As of 2015, there are 4 Federation organizations founded in İzmir with the name of the groups that had come from the Balkans and Rumelia. When the development of immigrant associations is examined, it is seen that while there were only 5 associations which were founded with the names "Kosova-Rumeli” (Kosovo-Rumelia), "Bal-Göç" (Bal-Immigration), "Makedonya" (Macedonia), "Mübadiller" (the Exchanged), and "Batı Trakya Türkleri” (Turks of Western Thrace) in İzmir in 1995, these groups were also subdivided within themselves, thereby increasing the number of associations. In 2015, the number of associations founded with the names "Makedonya" (Macedonia) and "Balkan" in İzmir is 37. Indeed, meeting under "one roof", which was aimed at in the suggestion of founding a federation to ensure activity in 2004 by the civil administrator (governor) then, could not be realized in 2015 either. This is also criticized particularly for causing "the loss of political power" in the evaluations of the groups within themselves. Moreover, it is complained that the number of registered members is not as high as expected considering the current number of immigrants, although the number of associations for the immigrants from the Balkans has increased. However, the scarcity of membership to the associations is related to immigrants' preference for not creating any reaction to them among their neighbors at the local level.

When analyzed as a whole, it is understood that the activities of becoming an association which are supported by the immigrants and in which they play a role are included in the "evaluation as being separatists" in the social 
life by the groups that do not call themselves immigrants.

Indeed, according to the author, the fact that the immigrant settlers mostly agreed to work at low wages in an unrecorded fashion besides becoming a political power through organization led to the occurrence of competition between their neighbors and them in the political and economic areas and created reactions among the nonimmigrant local people. In other words, the immigrant groups are able to establish group belonging and the area of contact with the local and central governments by means of these associations, whereas this political gap for the non-immigrant groups can only be filled "partially" by means of the parties.

On the one hand the immigrant people are organized so as to aim at using their political trumps well at the local and central levels, but on the other, they tend to form no gated communities by not losing contact with their neighbors within the neighborhood. Nevertheless, also considering that membership to the immigrant associations may be shown as a reason for being evaluated as an indication of standing apart from the society that they claim they actually belong to, the visibility of the union of powers is feared, as also noted previously. Briefly, while leader-centered associations successfully fulfill the function of "ensuring visibility in the public life" as they qualify as homogenous groups coming from a specific geography, they create good perception management regarding "potential votes".

Whether or not they have a noteworthy number of members, the Balkan Associations, as a mission, provide bureaucratic conveniences by contacting the administrative mechanisms via the commonality of the country of origin. Accordingly, the facilitative roles they conduct towards their members also pave the way for getting administrative and political roles at both local and national levels depending on the situation for their directors. In other words, association management and the mechanisms of an association's board of directors also fulfill the function of raising political leaders for local and national political arenas. Furthermore, now that a transition to the process of citizenship has been made since the 1980s the desire to raise personal awareness has generally become more important in the organization of associations in the context of developments like the improvements concerning rights in Bulgaria. This phenomenon also underlies the numerical increase.

"The citizen associations" with a Balkan name can play gradually more efficient roles in local elections. They can easily meet around educated individuals within them. Regarded as stores of potential votes corresponding to large numbers, the immigrant groups particularly draw the attention of mayors and/or mayoral candidates too. The political dance with the immigrants before an election and the bargaining for sending representatives to general/local elections turns out to be successful. The political preferences that the parties have developed to ensure prevalence in representation, which is related to democracy, have made the new immigrants an important political group.

In the final analysis, however, the immigrant citizens, whether or not they are members of any Balkan association, have the social comfort and benefit of "the presence of an association of theirs which is behind them". The evaluation of this phenomenon in terms of a non-immigrant citizen indicates some social tension in content. This issue is summarized below.

While the political immigration-oriented organization process of citizen associations maintains its speed, the efforts of becoming associations that also support grouping, revealing the ties of various countries and settlement units from abroad or within the country, offend the other local citizens who lack such ties, who came years ago, and who have made multidimensional contributions to the city. In connection with this, such groupings are initially evaluated within the perception of "threat" against local social integration, for the non-immigrant citizens have remained "lonely" within the crowd.

To turn the tables on them regarding the case leading up to this conflict and to accelerate social integration, the immigrant leaders invite their non-immigrant neighbors to sociocultural activities. E-communication means are used to enhance the widespread effect of the activities. It is thought that the tendencies towards grouping which are likely to occur in the society may also be prevented in this way.

\subsection{Visibility of the Immigrants in the Economic Life}

Turkey's rigid policy to prevent the presence of foreigners in the economic field, as in every field, has been gradually altered in favor of foreigners since the abrogation of Law No. 2007 on the Arts and Services allocated to Turkish Citizens in Turkey, dated 11.6.1932. It is seen that the possibilities for foreigners to work in Turkey were extended with "Law No. 4817 on the Work Permits for Foreigners", dated 2003. As a rule, the possibility of foreigners to work in Turkey has been bound to the condition of obtaining a "work permit", and the types and 
conditions of work permits have been organized within this scope. Even though Law No. 4817 generally closed only the strategic and public service business market to foreigners, it opened the education and working lives to foreigners depending on a permit within the framework of the European Union adjustment laws. However, although the regulations which facilitate the entry of foreigners of Turkish origin into the working life continue in favor of them step by step as compared with the other foreigners, the limitedness of its widespread effect is noted. Additionally, whom "the hidden regulations" implemented for the first time in the legal field concerning the working life protect is also a matter of hesitation among the immigrants. The predominant view is that especially the hidden regulations (inaccessible and debates are not open to public) extend the discretion of the administration and are planned for the conditional refugees who are of non-Turkish Origin and even have come from our eastern borders in the recent years. In this case, the reactions to those who are of non-Turkish origin and have come through irregular/forced migration have been added to the field of competition in the public sphere between the immigrants of Turkish origin and the citizens.

Both the immigrant settlers with a foreigner status and the immigrant settlers who acquired the Turkish citizenship took part in the working life by agreeing to low wages for long years. While the gross minimum wage was TL 886.50/USD 497.50 as of 2012 (without any tax or other deductions), the rate of those with an income equal to and under TL 750 is $32.1 \%$ in the sample. Whilst approximately one-third of the sample is below the minimum wage income level, those with an average monthly income of TL 1000 constitute $71 \%$ in the sample. However, the desire of parents to work and their tendency to work in several jobs increase the income earned by uncrowded families generally with 2 children.

It is understood that although they mostly completed their higher education in the country they had left in and after the 1980s, the immigrant individuals actually "had to accept" the low economic conditions they were provided with against the phenomenon of failing to enter the labor market in the process of citizenship in Turkey. The peace of mind stands out in the preference for Turkey. When the immigrants of identical origin working night and day so as to attain the quality of life they got used to in the country of origin that they had left and so as to own a house are asked their working hours, they can say 7 days and 24 hours. In the interviews, it was found out that after working on someone's account, they spent the remaining time completing the construction of their houses through collective work in parallel with the economic constraints. Nevertheless, being able to get established in these territories, to which they immigrated, which they adopted as the mother country, and with which they formed a relationship of belonging, is expressed as a challenging struggle the economic conditions of which vary by period.

While the unrecorded economic conditions are further complicating the problem of unemployment in Turkey, when it is failed to provide the economic environment intended to be opened administratively to those who come to Turkey through forced migrations and the convenient administrative conditions presented to them also to the citizens and the immigrants coming from different countries, this intensifies the group reaction against each other within them and the stress this causes complicates living in coexistence.

\subsection{Voting Right and Visibility in the Political Life}

In Turkey, the voting right (the right to elect and be elected) is acquired through citizenship. The immigrants who have acquired the voting right through citizenship can carry out their political activities in the regions densely populated by them more easily. Yet, it is emphasized by them that only being an immigrant alone is not efficient in the assessment of candidates and that the education, capability of representation and views of a candidate are also essential. Furthermore, they state that their preferences for political parties are not confined to the name of a party and that they also take the features of a party leader into account.

\section{Immigrants of Turkish Origin in İzmir Who Came from the Balkans}

In quantification, the research was based on questionnaires and in-depth interviews [14]. Due to group belonging, a discussion was made with the leaders and the opinion leaders and the support of the immigrant groups for the questionnaire study was obtained. The methodical approach of the research is outlined below.

\subsection{The Methodical Approach}

The immigrant groups that live in different regions of İzmir and that have acquired a Turkish citizen status have 
no distinct and officially kept records which show their origin. Therefore, their exact number is unknown. Thus, before the questionnaire study, estimated figures had been created with respect to the amount of the immigrant population as a result of the meetings with the members of the Balkan associations. The estimated populations of the immigrant groups in the regions densely settled by them are shown in Table 1.

On the basis of the data obtained from Table 1, the places densely inhabited in İzmir by the immigrant groups which constituted the target group of the study were determined and their shares in the percentage were calculated. In the literature, the formula developed by Cochran [15] is generally used to compute the number of samples (a). The sample volume calculated by means of this formula was determined as 382 with a $95 \%$ confidence rate and a 5\% error rate for a sample group assumed to consist of 58,407 people. In the context of this target sample group, the regional distribution predicted for the sample group of the study to be carried out in İzmir is shown in Table 2.

At the second stage of selection of the sample, the problem of how to reach the specified number of people was focused on and the snowball method was found appropriate as the sampling method. In this method, every individual who participated in the study was asked to refer the project team to a new individual and the sample was created so considering personal references. Importance was attached to the application of the questionnaires to the immigrants who came after the 1980s in particular. However, although the target of the sample was not fully attained because of the irregular working hours of the immigrant people, the questionnaires collected exceeded $79 \%$.

\subsection{Profile of Balkan and Rumelian Settlers in İzmir}

The profile of the immigrant settles in the surveyed areas is presented below.

Of the respondents, 35.3\% reside in Yeşilova, 25.7\% in Görece/Menderes, 23.4\% in Sarnıç, and 15.5\% in Atatürk Neighborhood, as it can also be seen from Table 3.

In the questionnaire applied to a total of 303 people, $66.7 \%$ of the respondents are male and $33.3 \%$ of them

Table 1. The regions inhabited by the immigrants in İzmir and their estimated populations (2011).

\begin{tabular}{cc}
\hline Neighborhood/District & Population \\
\hline Menderes Neighborhood (Görece-Sarnıç), Gaziemir & 6905 \\
Yeşilova, Bornova & 26,820 \\
Atatürk Neighborhood, Bornova & 24,682 \\
Total & 58,407 \\
\hline
\end{tabular}

Table 2. The distribution of percentages of the sample according to the regions inhabited by the immigrants.

\begin{tabular}{ccc}
\hline Neighborhood/District & Percentage in the Total Population & Number of Respondents \\
\hline Menderes Neighborhood (Görece-Sarnıç), Gaziemir & 0.12 & 45 \\
Yeşilova, Bornova & 0.46 & 176 \\
Atatürk Neighborhood, Bornova & 0.42 & 362 \\
Total & 1.00 & 382 \\
\hline
\end{tabular}

Table 3. Surveyed settlement units and the rates of participation.

\begin{tabular}{cccc}
\hline Settlement Units & Frequency & Percentage & Cumulative Percentage \\
Görece & 78 & 25.7 & 25.7 \\
Sarnıç & 71 & 23.4 & 49.2 \\
Yeşilova & 107 & 35.3 & 84.5 \\
Atatürk Neighborhood & 47 & 15.5 & 100.0 \\
Total & 303 & 100.0 & \\
\hline
\end{tabular}


are female. The respondents are predominantly at their forties to fifties. $82.8 \%$ of the respondents are married. $13.5 \%$ of the other respondents are single, and 3.3\% of them in total stated that they were separated from their spouses, divorced or were widowed. One respondent gave no answer.

Of the respondents, $89.8 \%$ were born in Bulgaria and 7.6\% in Turkey, as can also be followed from Table 4. Those who were born in Yugoslavia (1.3\%) and in Macedonia and Greece $(0.7 \%)$ were included in the sample. When asked from which country they had immigrated to Turkey, $95 \%$ of the respondents gave the answer "Bulgaria". A 5\% group from the remaining respondents migrated from Yugoslavia, Macedonia, and Greece. These rates also demonstrate that the target group for the questionnaire sample was attained.

\subsection{The Citizenship Status}

In Table 5, it was enquired whether the responding immigrants were Turkish citizens. Of the respondents, 55.1\% were double citizens, $43.9 \%$ were citizens of the Republic of Turkey, and $1 \%$ comprised the citizens of other countries. In fact, some of the immigrants of identical origin with a foreigner status preferred not to participate in the questionnaire as the process was ongoing, while some of them preferred not to do so because they went on staying in Turkey in spite of the expiration of their durations of residence. Nevertheless, the groups of Turkish origin with a foreigner status shared their problems concerning their inability to become citizens within the legal period they had expected.

In the in-depth interviews, it was pronounced that the government's preference for the presence of groups with a Turkish identity that were not its citizens in the Balkans was effective on this delay, which appeared in the naturalization of the foreigners of Turkish origin.

When the education statuses of the respondents are examined, it is seen that they lived in an environment with limited educational conditions as most of them came to Turkey when they were children. Only $1 \%$ of the respondents stated that they were illiterate. Those who were literate constituted a small group at the rate of 5.9\%. The graduates of secondary education constitute the majority with a rate of $54.5 \%$. Those who received undergraduate and higher education are the young group aged around 30 years, with their rate being $15.8 \%$ (48 people). The rate of those with no answer is $2.6 \%$.

The fact that the immigrants are of Turkish origin may encourage one to think that no problem is experienced in terms of communication in Turkish. Of the immigrants, $16.2 \%$ do not know any language other than Turkish, while $44.9 \%$ know a language other than Turkish. Moreover, the rates of those who know 2 and 3 languages are

Table 4. Place of birth.

\begin{tabular}{cccc}
\hline Place of Birth & Frequency & Percentage & Cumulative Percentage \\
\hline Bulgaria & 272 & 89.8 & 89.8 \\
Turkey & 23 & 7.6 & 97.4 \\
Yugoslavia & 4 & 1.3 & 98.7 \\
Macedonia & 2 & 0.7 & 99.3 \\
Greece & 2 & 0.7 & 100.0 \\
Total & 303 & 100.0 & \\
\hline
\end{tabular}

Table 5. The citizenship status.

\begin{tabular}{|c|c|c|c|c|}
\hline Citizenship & Frequency & Percentage & Valid Percentage & Cumulative Percentage \\
\hline Citizen of the Republic of Turkey & 132 & 43.6 & 43.9 & 43.9 \\
\hline Double Citizen & 166 & 54.8 & 55.1 & 99.0 \\
\hline Other & 3 & 1.0 & 1.0 & 100.0 \\
\hline Total & 301 & 99.3 & 100.0 & \\
\hline Unanswered & 2 & 0.7 & & \\
\hline Total & 303 & 100.0 & & \\
\hline
\end{tabular}


$29.4 \%$ and $9.6 \%$, respectively. This result is extremely natural.

The immigrants indeed know the official language of the country from which they came, and they entered the working life by receiving education in this language. Likewise, the languages known other than Turkish include Bulgarian at the rate of $72.61 \%$. The second language known is Russian at the rate of $34.98 \%$. Of the other languages, English, French and German are known at the rates of $11.55 \%, 4.29 \%$, and 3.30\%, respectively. The languages other than them are known by 4 or fewer people. What is important in this process is the fact that the immigrants carry on their preference for speaking Turkish.

When Table 6 is examined, it is seen that a group at the rate of $65.4 \%$ that immigrated to Turkey came to the country 20 - 40 years ago, excluding those with no answer. The rates of periodic arrivals in Table 6 show the presence of continuous migrations from the Balkans, particularly from Bulgaria, by year. Likewise, the rate of migrations earlier than 40 years is $5.3 \%$, whereas the rate of migrations until the last 20 years is $14.3 \%$, which is almost three times more than this value. The stepwise arrivals of the families in Turkey provided this continuity.

According to the distribution of rates in Table 7, where the periods of settlement of the immigrant groups in İzmir are evaluated, it is seen that a significant rate of immigrants $(71.7 \%)$ have been living in İzmir since the first day of their arrival in Turkey, with a time frame of 20 to 40 years. Likewise, when evaluated together with Table 8, those who state that İzmir is their first settlement area are found to constitute $79.3 \%$.

During the interviews, the groups that came from the Balkans with their internalized sociocultural conditions explicitly stated that İzmir was the first preferred place as it did not remain outside the quality of life standards they got used to. These statements are also in agreement with the settlement theories concerning the fact that social

Table 6. Period of years lived in Turkey.

\begin{tabular}{cccccc}
\hline & Years in Turkey & n & Percentage & Valid Percentage & Cumulative Percentage \\
\hline Life & $2-19$ Years & 46 & 14.3 & 14.7 & 14.7 \\
Years & $20-40$ Years & 238 & 65.4 & 79.5 & 94.3 \\
& $41-67$ Years & 17 & 5.3 & 5.7 & 100.0 \\
Total & 299 & 98.4 & 100.0 & \\
& Unanswered & 5 & 1.6 & \\
\\
General Total & 304 & 100.0 & \\
\hline
\end{tabular}

Table 7. Period of years lived in İzmir.

\begin{tabular}{cccccc}
\hline Years in İzmir & $\mathbf{n}$ & Percentage & Valid Percentage & Cumulative Percentage \\
\hline $2-19$ Years & 66 & 21.7 & 22.1 & 22.1 \\
$20-40$ Years & 218 & 71.7 & 73.2 & 4.8 \\
Life Years & $41-67$ Years & 14 & 4.6 & 100.0 \\
Total & 298 & 98.0 & 2.0 & \\
& Unanswered & 6 & 100.0 & \\
\hline
\end{tabular}

Table 8. İzmir as the first settlement area after immigration into Turkey.

\begin{tabular}{cccccc}
\hline & First Settlement & n & Percentage & Valid Percentage & Cumulative Percentage \\
\hline Yes & 241 & 79.3 & 81.4 & 18.6 \\
No & Total & 55 & 18.1 & 97.4 \\
& 296 & 2.6 & 100 \\
Unanswered & 8 & 100.0
\end{tabular}


opportunities initially came actually before economic opportunities in the preferences for settlements in voluntary migrations. We may think that the immigrants with such feelings cannot be a source of social opposition in İzmir.

The preference for immigration into another country when better living conditions form is essential as an important finding as to social belonging. The responses to this question are in Table 9 .

When the effect of better quality of life conditions on directing to re-migrate to a country is examined as in such enquiries that are of use to the quantification of belonging, it is seen that $85.2 \%$ responded with "No" in Table 9, stating that there would be no migration back from Turkey or no migration to another country. It is understood that the immigrants are not willing to emigrate from Turkey, which they consider the mother country.

\subsection{Areas Settled by the Non-Immigrant People}

To explore the presence of sociocultural relations between the immigrants in İzmir and the neighboring people, a questionnaire study was applied in Görece, Sarnıç, Yeşilova, and Atatürk Neighborhood. In Table 10, it is seen that of the non-immigrant local people included in the sample, 68.6\% resided in Görece, $12.7 \%$ in Atatürk Neighborhood, 9.8\% in Sarnıç, and 7.8\% in Yeşilova.

Of the local people who are non-immigrants but use the same space with the immigrants and who are included in the questionnaire sample, $67.6 \%$ are male and $31.4 \%$ are female, with them being around 45 years of age. Of the respondents from the local people, $66.7 \%$ are married and $24.5 \%$ are single. Those who were separated from their spouses, divorced, were widowed or others constitute $8.8 \%$.

Of the respondents, $41.2 \%$ are primary school graduates and $33.3 \%$ are secondary school graduates. Regarding the education level, the rate of literate respondents is $4.9 \%$, whereas the rate of illiterate respondents is $2 \%$. The undergraduate and higher-level education group constitutes $18.6 \%$. These values reveal that the immigrants live in coexistence with the people from the local public who are relatively less educated than them.

In Table 11, the local people were asked with which groups they spent time outside the family environment in terms of neighborhood relations. The evaluation is as follows.

When Table 11 is examined, it is seen that in the question "With which groups do you utilize your leisure apart from your family?", the local people revealed that they attached importance to spending time with their own groups at the rate of $52 \%$. Being together with the neighboring immigrant groups constitutes $10.8 \%$. While the rate of immigrant neighbors and others is $9.8 \%$, the option "other" constitutes $24.5 \%$ as "friends". The

Table 9. The preference for immigration into another country when better quality of life conditions form?

\begin{tabular}{ccccc}
\hline Options & Frequency & Percentage & Valid Percentage & Cumulative Percentage \\
No & 259 & 85.2 & 89.0 & 89.0 \\
Yes & 32 & 10.5 & 11.0 & 100.0 \\
Total & 291 & 95.7 & 100.0 \\
Unanswered & 13 & 4.3 & \\
General Total & 304 & 100.0 & \\
\hline
\end{tabular}

\section{Table 10. Settlement area.}

\begin{tabular}{cccc}
\hline Settlement Area & Frequency & Percentage & Cumulative Percentage \\
\hline Görece & 70 & 68.6 & 68.6 \\
Sarnıç & 10 & 9.8 & 78.4 \\
Yeşilova & 8 & 7.8 & 86.3 \\
Atatürk Neighborhood & 13 & 12.7 & 99.0 \\
Unanswered & 1 & 1.0 & 100.0 \\
Total & 102 & 100.0 & \\
\hline
\end{tabular}


friends also encompass the circle of colleagues. When the direction of preference for settlement in the neighborhoods densely settled by the immigrants included in Table 12 is analyzed, it is seen from this question that although the living of local people with the immigrant groups is not their first choice, they are able to carry on their lives in the neighborhoods densely populated by the immigrants; furthermore, there is a group that considers this matter insignificant (26.5\%).

According to the information in Table 12, the willingness of the local people to reside in a neighborhood with immigrant neighbors is at the rate of $40.2 \%$. It was understood that $60 \%$ of the local people were not concerned with whether their neighbors were immigrants. Accordingly, it can be clearly stated that there is no great sociocultural distance between both groups.

Whilst only $8.8 \%$ responded negatively to the question "How do you evaluate the settlement of immigrants in your neighborhood?" (Table 13), the rate of those who positively viewed the settlement of immigrants is 53.9\%. These results are in agreement with the results in Table 12.

When the neighborhood relations of the local people in Table 14 with the immigrant groups are examined, it is understood that $58.8 \%$ of the local people have immigrant neighbors and that the local people remain at around $40 \%$. In fact, this result was observed in the field. The neighborhood relations in the neighborhoods predominantly settled by the immigrant groups develop positively since the settled immigrant groups are considered to have positive values due to their profiles. The positive evaluations of visibility in the economic life-a risky area of competition for the immigrant groups-are available in Table 15.

Table 11. Spending the leisure outside the family.

\begin{tabular}{ccccc}
\hline Spending Time outside the Family & N & Percentage & Valid Percentage & Cumulative Percentage \\
\hline Neighboring Immigrant Groups & 11 & 10.8 & 10.8 & 10.8 \\
Local People & 53 & 52.0 & 52.0 & 62.7 \\
Other & 25 & 24.5 & 24.5 & 87.3 \\
Neighbor and Immigrant & 10 & 9.8 & 9.8 & 97.1 \\
All & 3 & 2.9 & 2.9 & 100.0 \\
Total & 102 & 100.0 & 100.0 & \\
\hline
\end{tabular}

Table 12. Preference for settlement in the neighborhoods densely populated by the immigrants.

\begin{tabular}{ccccc}
\hline Preference for Settlement & $\mathbf{n}$ & Percentage & Valid Percentage & Cumulative Percentage \\
\hline Yes & 41 & 40.2 & 41.0 & 41.0 \\
Unimportant & 27 & 26.5 & 27.0 & 68.0 \\
No & 6 & 5.9 & 6.0 & 74.0 \\
I Have No Idea & 26 & 25.5 & 26.0 & 100.0 \\
Total & 100 & 98.8 & 100.0 & \\
Unanswered & 2 & 2.0 & & \\
General Total & 102 & 100.0 & \\
\hline
\end{tabular}

Table 13. Perception of settlement of immigrants in the neighborhood.

\begin{tabular}{ccccc}
\hline Expression of Scale & N & Percentage & Valid Percentage & Cumulative Percentage \\
Positive & 55 & 53.9 & 53.9 & 23.5 \\
Unimportant & 24 & 23.5 & 13.7 & 8.8 \\
No Idea & 14 & 13.7 & 100.0 \\
Negative & 9 & 8.8 & & 100.0 \\
Total & 102 & 100.0 & & \\
Total & 102 & 100.0 &
\end{tabular}


Table 14. Neighborhood relations with the immigrant groups.

\begin{tabular}{ccccc}
\hline Options & n & Percentage & Valid Percentage & Cumulative Percentage \\
\hline Yes & 60 & 58.8 & 58.8 & 58.8 \\
No & 42 & 41.2 & 42.2 & 100 \\
Total & 102 & 100.0 & 100.0 \\
Unanswered & 0 & 0 & \\
Total & 102 & 100.0 & \\
\hline
\end{tabular}

Table 15. Local people's perception of the presence of immigrant settlers in the working life.

\begin{tabular}{ccc}
\hline General Classification & Frequency & Percentage \\
\hline Positive & 59 & 59.5 \\
Harmless & 11 & 11.1 \\
Negative & 12 & 12.1 \\
Has No Idea & 17 & 17.1 \\
Total & 100 & \\
\hline
\end{tabular}

By providing an open-ended type of question in Table 15, the local people were allowed to express their feelings in their own sentences. According to the evaluations, 59.5\% of the people find the participation of immigrants in the working life positive, whereas $11.1 \%$ of them state that the case will not disturb them and $12 \%$ of them indicate the negativity of participation in the working life. The respondents from the local people who positively view the participation of immigrants in the working life indeed evaluate the immigrant groups of Turkish origin as hardworking, disciplined, and learned. The greatest reason why the local people consider the immigrant groups negative is that they lead to a decrease in prices under the free market conditions by agreeing to work at low wages in an unrecorded fashion.

According to Table 16, the participation of immigrants in organizations like "immigrant associations" was found useful by $55.9 \%$ of the local people. Those who say "I find it of no use" constitute $12.7 \%$. Those who state that they consider it very inconvenient constitute $3.9 \%$. The rate of those who do not state their idea is $27.5 \%$. The perceptions of the negativity of becoming an association constitute $44 \%$ in total.

The non-immigrant local people were asked how they would evaluate the case if the immigrant groups were granted the right to vote in local elections without becoming citizens. The rates of those who responded to this question as "I find it useful", "I find it of no use", and "very inconvenient" are $41.2 \%, 22.5 \%$, and $26.5 \%$, respectively. The negative evaluations of the right to vote reach a significant rate of $58 \%$ together with those with no idea on this matter. The percentages of having no idea are relatively low (8.8\%) in comparison with the other tables. In this study, "being a citizen” stood out as an important criterion for coexistence. Immigrants' voting in local elections within the legal foreigner status is not considered positive substantially.

In summary, an overwhelming majority of the respondents define the immigrants with their positive aspects. The immigrants are in the top three ranks regarding their positive features at the rates of $77.7 \%, 65.6 \%$, and $52.5 \%$, respectively. The features described with positive expressions are concentrated on the fact that the immigrants are hardworking, thrifty, and clean. Some of the respondents evaluate the immigrants with their negative aspects at the lowest rate of $6.6 \%$ and at the highest rate of $8.8 \%$. The most expressed features in this group include being selfish, utilitarian, and materialistic. In the final analysis, the immigrant groups of Turkish origin are considered "reputable groups" in the society because of their being educated and thanks to their positive behaviors in the social sphere despite the presence of conflicts between the non-immigrant local people and them in terms of economic competition.

When similar issues (cultural identity and visibility in the public life as the right to vote) are evaluated in terms of the foreigners of European origin, it is seen that the Turkish citizens attach considerable importance to identity, belonging, and the rights to vote. Regarding the settlement of European foreigners in Antalya, local people indicated "degeneration of values" (46.9\%), "degeneration of the native culture" (45.9\%) and "increase 
Table 16. Social perceptions of participation of the immigrants in organizations like "immigrant associations".

\begin{tabular}{ccccc}
$\begin{array}{c}\text { Perception of Participation of } \\
\text { Immigrants in Immigrant Associations }\end{array}$ & $\mathbf{n}$ & Percentage & Valid Percentage & Cumulative Percentage \\
\hline I Find It Useful & 57 & 55.9 & 55.9 & 55.9 \\
I Find It of No Use & 13 & 12.7 & 12.7 & 68.6 \\
Very Inconvenient & 4 & 3.9 & 3.9 & 72.5 \\
I Have No Idea & 28 & 27.5 & 27.5 & 100.0 \\
Total & 102 & 100.0 & 100.0 & \\
\hline
\end{tabular}

in unrecorded work" (11.5\%) as being the most unfavorable factors. On the other hand, 28.7\% indicated "the increase in economic prosperity", 20.2\% “multiculturalism and tolerance”, 10.3\% "achievement of democratic environment”, 7.9\% “increase in urban security" and 4\% "less bureaucracy” as favorable factors. Incomers through migration are a serious problem in Antalya as regards the alteration of the perception of a secure city [16].

When the values to determine "the social perceptions provided that the European foreigners acquire the Right to Vote in Local Elections" in Turkey are examined, it is seen that the rate of those who state that they consider the developments as to the studies for foreigners' right to vote in local elections in Europe of no use to Turkey is $41.8 \%$ in a 505-person sample from the local people. A group at the rate of $19.8 \%$ expresses this development and/or change regarding the use of political rights with the evaluation "very inconvenient”. The rate of negative evaluations is $61.6 \%$, while the rate of those who did not answer is $7.9 \%$ [17] [18]).

Also in the studies on the asylum seekers who came through external migration, the settled citizens stated that they did not want the irregular incomers from the east and the south-east for citizenship (80\%) and sought “a cultural bond" rather than religious fellowship but could not find it (70\%) and they expressed that they perceived the migrations particularly from regions like Syria as a "threat” [19] (Table 17).

\section{Conclusions and Evaluation}

Irrespective of their cause, the issue of large population movements and immigrants has been an active ground that public administrations always consider important and it has been at the center of biopolitical strategies throughout the history of mankind. Today, global relations/networks (nature, economic activities, and communication networks) trigger migration movements. The failure to manage the phenomena of internal and external migrations well in Turkey is evaluated as an administrative failure. It is doubtlessly essential that immigrants are utilized as "human capital" in social, technical, and economic dimensions. However, it is not easy to immediately embrace administrative and social acceptances owing to the factor of confidence. Now that the fundamental basis for administrative strategic approaches is rightfully social security, the method to be applied in the case of accepting the immigrants is to include them in cultural and socio-economic activities by not leaving them to their own devices and support these networks of social relations.

\section{What Might Be the Strategic Approaches Which Take the Impacts of External Migrations into Consideration?}

The types of migration performed by the European immigrants who come to Turkey from developed regions like Europe voluntarily and through legal ways and by the immigrants of Turkish origin who come from Europe and the forced migrations from the eastern borders of Turkey must be considered separate from each other. These migrations might take place for business, educational, and political purposes or under the coercive impact of climate changes. The immigrants of Turkish origin were headed for Turkey as they had more longings for being in social unity. Basic strategic approaches to the immigrants are proposed below on the basis of the research into the immigrants of Turkish origin and with the accumulation of knowledge gained: 
Table 17. Social perception of immigrants' obtaining of the right to vote in local elections without becoming citizens.

\begin{tabular}{ccccc}
\hline Perception of Voting in Local Elections & N & Percentage & Valid Percentage & Cumulative Percentage \\
\hline I Find It Useful & 42 & 41.2 & 41.6 & 41.6 \\
I Find It of No Use & 23 & 22.5 & 22.8 & 64.4 \\
Very Inconvenient & 27 & 26.5 & 26.7 & 91.1 \\
I Have No Idea & 9 & 8.8 & 100.0 & 100.0 \\
Total & 101 & 99.0 & & \\
Unanswered & 1 & 1.0 & & \\
Total & 102 & 100.0 & & \\
\hline
\end{tabular}

- In their migration preferences, foreigners of Turkish origin and other foreigners prefer the settlements with which they can form a sociocultural affinity in the country as well.

- When favorable economic conditions like the property right are administratively created for the immigrants even in the case of immigrants of Turkish origin, the local people perceive this case as an inequality created by the administration and may react despite the common origin. It is important that the public administration not creates any differences in service also by providing administrative support in terms of the local people particularly in the regions where it places the immigrants and the other immigrant groups by itself.

- For the nonoccurrence of social unrest, it is essential that the administration takes administrative pains to provide specific strategic conditions according to the geographical and social environments when it leaves the immigrants to their own devices in their preferences for settlements depending on the situation.

- It is important that joint social and cultural studies are carried out with the support of local governments and the local people in those regions where the immigrants have settled. These studies are essential to raise the social confidence threshold.

- In the types of migration performed by the groups with no common language with the local people, it is important that the administration implements a common education program in order to ensure communication.

- It is important that the support of the nongovernmental organizations is received multidimensional in the sociocultural studies through the harmonization programs for the new immigrants placed at the periphery of the settlements.

- The supporting of academic studies on immigrants is important in strategic studies.

- It is important that the case is determined in order to benefit from the knowledge and skills of the immigrant population and from the positive impacts of their entrepreneurship and that capacity building studies with public, private, and civil partners are developed.

- While the administration paves the way for the better use of economic opportunities for new immigrants in migration management, the legal/institutional regulations to create a feeling of competition between the citizens as previous settlers and them should not be made.

- Mutual alienation may arise owing to the disagreement between the interests even if the immigrants have a common origin with the local people. To prevent completely different cultural structures and individual/ group behaviors far from modern-ethical acceptances, distinct pains should particularly be taken to females and children and capacity building studies should be developed concerning them.

- The citizen associations founded to ensure social harmony may move away from their goal in time and tend to establish some distinct power from the local people through collecting political rent and/or through solidarity. This behavior is evaluated as a perception of threat by the local people. In order not to lead to social clashes, it is important that mechanisms to improve democracy are developed for everyone in the country starting from the local level.

- It is important to develop legal/institutional negotiation environments that might be effective on the development of democracy, which are appropriate for the administrative structure of the country such as city councils and development agencies, and which are in agreement with the principles of the Council of Europe.

- Multidimensional specialized support should be provided by generating social training programs for the im- 
migrants primarily by universities.

- Some of the external migrations encompass those who come to Turkey from the eastern countries in order to reach better living conditions and to attain a refugee status by seeking asylum again due to the fear of death. Such forced migrations require distinct administrative care. It is important that groups of asylum seekers/ refugees definitely are placed in the country within the knowledge of the administration and not be left to their own devices. Those who come through forced migration are not socially accepted due to their different cultural behaviors in the regions where administrative controls remain poor and where they settle, and there occur social tensions which reach a clash. In this case, owing to different risk factors, the newcomers and the settlers may experience unjust treatments which vary by case. The attitudes and strategies of the public administration towards migration management should be to ensure that primarily the classical security duties of the state and the other quality of life indicators are not leveled down.

- The immigrants, particularly the children, need the tolerance by previous settlers/local people. On the other hand, the settled people also regard themselves as being unjustly treated when there is a decrease in the quality of life that they have got used to. Therefore, the administration should produce new risk and crisis scenarios against the immigration which leads to its unpreparedness and which qualifies as a sudden arrival as well as develop strategies by carrying out event rehearsal studies in order not to lead to applications which will confront the groups with each other.

- It is important that the periods of a transition to the citizen status by those who come to Turkey are not shortened for the individuals and/or groups of non-Turkish origin and that the projects of social integration with the local people are developed. In addition, good management of the economy is essential in order not to create any unrecorded economic cases.

- Even though the common issue of the phenomenon of migration is the mostly irregular, rapid, sudden, and gradually arriving population mobility, it is necessary to develop different administrative strategies suitable for different types of migration as the requirements and characteristics of each type of migration are more or less distinguished from each other.

- In Turkey, there are no comprehensive administrative studies which divide the migration movements according to their characteristics. Moreover, what is more important is that there are no reliable settlement statistics which show the population mobility in settlements or any inventories of profile of the population that immigrated to Turkey. Strategies to access updated figures and to ensure their sustainability should be studied. The experiences of countries like the United Kingdom may be utilized to this end.

- Although "the Migration Administration" (2012) for migration management was officially founded at a late date, it conducts useful studies. The supporting of the studies of the Migration Administration through extensive academic research should be maintained in order to develop appropriate strategies.

- Depending on the definitions of types of migration and the diagnosis of the profiles of incomers, their legal responsibilities in the public sphere should be specified and their rights and obligations should be analyzed. Determination of the local and regional impacts of the pressure by the immigrant population, the planning of migration management and the multidimensional planning of the settlement of the immigrant population in urban and rural settlements are essential issues.

- The different educational, sociocultural and economic characteristics of the immigrants create the fear of not finding a job especially owing to economic problems among the local people. This feeling is an important source of stress which is effective in damaging the neighborhood relations.

- The most important issues negatively affecting crisis management in the events which create a risk of "security" for economic, social, political, and natural reasons in public administration are the lack of sociocultural harmony or cultural clashes and the lack of social insecurity. Thus, the culturally integrating studies should be included in the most important issues of migration management planning.

- Local, regional and national migration management planning is essential in terms of urban and national security with economic, natural, political, and military dimensions. It is also important that the units within the central and provincial organizations of public administration ensure corporate governance among each other and develop social reconciliatory strategies at every opportunity according to the structure of the administrative echelons.

\section{References}

[1] Toprak, Z. (1990) Kıyı Yerleşimlerinde Turizm Faaliyetleri ve Belediyelerin Karşıllaştıkları Sorunlar: Çeşme Belediyesi 
Örneği, Amme İdaresi Dergisi, 23, 127-128.

http://www.todaie.edu.tr/resimler/ekler/4f89691f00e5471_ek.pdf?dergi=Amme\%20\%DDdaresi\%20Dergisi

[2] Karaman, Z.T. (2012) An Emprical Study of the Effects of Social And Cultural Differences of Foreign Retired Residents on Local Citizens around Antalya Area of Turkey. International Journal of Business and Social Science, 3, 206-216.

[3] Karaman, Z.T. (2014) 2023'e doğru Yerel Yönetimler. EGİAD Yarın Journal, 14, 45-49.

[4] BBC (2015). http://www.bbc.com/turkce/haberler/2015/06/150615_suriye_multeci_avrupa

[5] Anadolu Ajans1 (2015). http://www.aa.com.tr/tr/manset/558893--sanliurfada-patlama

[6] Karaman, Z.T. (2012) An Analytical Study of Turkish Immigrants and Other Foreigners in the United Kingdom in Terms of the Philosophy of the Council of Europe. American International Journal of Contemporary Research, 2, 2740.

[7] Çağlayan, S. (2006) Göç Kuramları, Göç ve Göçmen İlişkisi, Muğla Üniversitesi Sosyal Bilimler Enstitüsü Dergisi (ILKE), 17, 68-89.

[8] Law No. 6458 (2015). http://www.goc.gov.tr/files/files/YUKK_I\%CC\%87NGI\%CC\%87LI\%CC\%87ZCE_BASKI.pdf

[9] BBC News (2015). http://www.bbc.com/turkce/haberler/2015/04/150425_wow_suriyeli_kadinlar_kurtaj

[10] Rörig, F. (1946) Avrupa Şehirlerinin Doğuş ve Gelişme Tarihi, İdare Dergisi, Cemil Ziya Şanbey(translator) 17/181, 136.

[11] According to the Official Data of Turkey in 2014, İzmir Is the Third Province with a Population of 4,113,072 People. It Is Located in the West of the Anatolian Peninsula and in the Middle of the Aegean Region. Local Services Are Fulfilled by the Metropolitan Municipality Government Structuring in İzmir, Located Around the Gulf of İzmir. The General Administration of the Province Is Carried out by the Governor. It Is an important Seaport.

[12] Bang, H. and Esmark, A. (2013) A Systems Theory of Good Governance ICPP, Grenoble. Pane 45/Session 1. http://www.icpublicpolicy.org/IMG/pdf/panel_45_s1_esmark.pdf

[13] İzmir Dernekler Dairesi Başkanlığı (2015). http://www.dernekler.gov.tr/tr/Anasayfalinkler/illere-gore-faal-dernekler.aspx

[14] The Database of This Study, Which İs Reflected in the Tables, Was Developed within the Scientific Research Project of Dokuz Eylul University (2010-2012) on "Making the Immigrants of Turkish Origin Who Came from Bulgaria and Settled in İzmir Visible in the Public Sphere and Ensuring their Harmony with the Society”, Directed by Zerrin Toprak Karaman (the Author). The Research Team of the Project İncluded Zerrin Toprak Karaman and Ömür N.T. Özmen as Well as Yunus Emre Özer, Gökhan Tenikler, İbrahim Güray Yontar, Özlem Çakır, Duygu Türker, and S. İlkim Kaya. The Contents of the Paper Were Written in Agreement with İts Title by the Author.

[15] Cochran, W.G. (1963) Sampling Techniques. 2nd Edition, John Wiley and Sons Inc., New York, 75. https://edis.ifas.ufl.edu/pd006

[16] Karaman, Z.T. (2012) An Emprical Study of the Effects of Social And Cultural Differences of Foreign Retired Residents on Local Citizens Around Antalya Area of Turkey. International Journal of Business and Social Science, $\mathbf{3}$, 212.

[17] Toprak, Z. (2009) Yabancı Emekli Yerleşiklerin Yerelde Kamusal Hayata Katılım istekliliği ve Yerel Halkla İlişkileri: Antalya İçin Bir Yaklaşım, 125. http://dergipark.ulakbim.gov.tr/comuybd/article/viewFile/5000037328/5000036203

[18] Karaman, Z.T. (2008). http://www.todayszaman.com/diplomacy_expats-not-keen-on-voting-in-elections_158389.html

[19] CNN Türk (2015) The Program "Eğrisi Doğrusu", from the Notes about the Research on the History of Migration, Broadcast/a Publication by Bilgi University. http://www.bbc.com/turkce/haberler/2015/04/150425_wow_suriyeli_kadinlar_kurtaj 